\title{
Model Based Analysis of Innovation in Sustainable Supply Chains
}

\author{
Jesús Morcillo-Bellido *(D), Luis Isasi-Sanchez (D), Isabel Garcia-Gutierrez (D) and Alfonso Duran-Heras (D) \\ Escuela Politécnica Superior, Área de Ingeniería de Organización, Universidad Carlos III de Madrid, \\ Avenida de la Universidad, 30, Leganés, 28911 Madrid, Spain; lisasi@ing.uc3m.es (L.I.-S.); \\ igarcia@ing.uc3m.es (I.G.-G.); duran@ing.uc3m.es (A.D.-H.) \\ * Correspondence: morcillo@ing.uc3m.es; Tel.: +34-91-6248765
}

Citation: Morcillo-Bellido, J.; Isasi-Sanchez, L.; Garcia-Gutierrez, I.; Duran-Heras, A. Model Based Analysis of Innovation in Sustainable Supply Chains. Sustainability 2021, 13, 4868. https://doi.org/10.3390/ su13094868

Academic Editor: Juan-José Alfaro-Saiz

Received: 31 January 2021

Accepted: 22 April 2021

Published: 26 April 2021

Publisher's Note: MDPI stays neutral with regard to jurisdictional claims in published maps and institutional affiliations.

Copyright: (C) 2021 by the authors. Licensee MDPI, Basel, Switzerland. This article is an open access article distributed under the terms and conditions of the Creative Commons Attribution (CC BY) license (https:// creativecommons.org/licenses/by/ $4.0 /)$.

\begin{abstract}
Innovation supports the development of Sustainable Supply Chains (SSCs) through Sustainability-Oriented Innovation (SOI) practices. This study aims to validate and further develop, through its practical application, a baseline SOI practices framework, which can be used as a benchmark model. While applying and validating this framework, several new, conceptually distinctive SOI practices were identified that were not included in the proposed baseline model. This led the authors to propose expanding the initial baseline model with a new category of "transversal" SOI practices, so that the expanded model provides a more comprehensive view of the mechanisms that foster innovation at SSCs. These "transversal" SOI practices are highly contingent on the adopting company's traits and strategy, thus suggesting that they might be a major conduit through which its strategy is reflected in its SSCM. Besides their transversal and contingent nature, another key trait of the identified SOI practices is their integrated, dynamic, time-dependent, feedback-loopbased interrelationship. These findings suggest the potential effectiveness, for processes such as sustainability innovation that involve substantial time lags, to reposition top management focus and performance evaluation "upstream" in the causal chain. This potentially promising approach involves shifting focus from results (particularly short-term results) to its causes (processes, methods), and systematically managing the ensuing feedback loops.
\end{abstract}

Keywords: innovation; sustainability; Supply Chain (SC); Sustainable Supply Chain (SSC); Sustainability-Oriented Innovation (SOI); SOI practices; innovation frameworks

\section{Introduction}

\subsection{Sustainability, SCM, and GrSCM/SSCM}

The growing awareness on sustainability, and the ensuing research focus, has converged with the management and research streams focalized on the management of the Supply Chain, leading to the emergence of the Green Supply Chain Management (GrSCM)/Sustainable Supply Chain Management (SSCM) approaches.

The imperative for changes in industrial, commercial, and consumption practices were the main focus of the Brundtland report [1]. Since the late 1990s, sustainability has been a subject of permanent interest among academics and managers concerned with long-term improvement $[2,3]$. Shareholders, public entities, suppliers, and consumers began to exert pressure, from different angles, prodding organizations to reconsider their business models, and questioning the repercussions of business practices on society and environment [4].

Since the 1990s, there has been a spike in the published literature on Supply Chain Management (SCM) [5,6]. Mentzer et al. [7] define the supply chain as a strategic and systematic integration of traditional business functions with the purpose of improving long-term results, both for each company participating in the chain and for the entire supply chain itself. Some years later, Lambert et al. [8] established that the supply chain implies an integration of processes from the first supplier to the final customer, with the aim of providing products, services, and information that add value for the customer and for the rest of the stakeholders. 
The integration of these two management and research streams, on sustainability and on SCM, led to the emergence of the Green Supply Chain Management (GrSCM)/Sustainable Supply Chain Management (SSCM) approaches, within the wider arena of the Corporate Social Responsibility (CSR).

Thus, since the late 1990s, the focus of SCM was reoriented towards issues concerning sustainability in supply chains $[9,10]$. Initially, studies were focused on narrowly defined issues such as the application of Operation Research tools to environmental issues [11]. However, this initial narrow scope promptly developed into a fully-fledged integration of the sustainability perspective within the realm of SCM. Since the early 2000s, sustainability became recognized as a management area that integrated environmental and social issues along with economic and organizational objectives [12]. The high relevancy of this sustainability trend for actual SCM is illustrated by the fact that in the early 2000s, companies such as Ford Motors Company, Philips, and Sony started requiring its suppliers to achieve ISO 14,000 certification or other sustainability standards. Furthermore, other top leading companies like Adidas, Nike, and Walmart started taking steps to ensure the application of sustainability-oriented practices throughout their supply chains [13].

Among the most likely main drivers for the growing priority attached to sustainability in SCM were both the growing exploitation and pollution of natural resources, and the ensuing government and customer awareness that led to the enactment of new norms and laws. This awareness led to the development of the so-called Green Supply Chain Management (GrSCM), focused on the environmental impact evaluation of the SC activities [14-17]. GrSCM is sometimes conceived as solely focused on the environmental and economic aspects of the supply chain. However, this narrow definition fails to encompass the social aspects that are undoubtedly involved at any supply chain. Some authors, such as Roehrich et al. [18], focus particularly on the potential benefits of properly conducting Green Supplier Selection (GSS). While carrying out an in-depth case analysis of a SC within the aerospace sector, they extend their analysis further upstream of the wider SC, beyond the usual buyer-supplier "dyad". They adopt the first-tier supplier's perspective and apply self-determination theory (SDT) to explore how actually achieving the stated sustainability objectives hinges, to a large extent, on the second-tier suppliers' value internalization. They consider, in line with some relevant previous research [19-21], that GrSCM could generate benefits including stronger brand recognition, cost-saving, and competitor differentiation.

This focus on the supply chain implications of environmental and social factors, combined with economic factors, has continued and intensified, thus attracting a significant number of researchers and practitioners in recent years [14,22-24]. Thus, the study of the management of the so-called Sustainable Supply Chain (SSCM) has evolved as an extension of the management of the Supply Chain (SCM), however, also integrating the environmental and social angle [25-27]. Some authors have explored the relationship between SSCM and related SC approaches, such as Total Quality Management (TQM) and Lean management; authors such as Dey et al. [28] consider that SC lean practices help to achieve sustainability performance.

SSCM is recognized by many companies as a potential source of competitive advantage; some have tried to develop "order winners" based on sustainable practices in their supply chains. SSCM entails applying "clean solutions" in line with the objectives of the organization [9,14,29,30]. Authors such as Dubey et al. [31] identified specific SSCM drivers like green warehousing, strategic supplier collaboration, environmental practices continuous improvement, information technology applications, logistics optimization, social values and ethics, sustainable corporate strategy, economic stability, and sustainable products design. Grosvold et al. [32] build on Hervani et al. [33] research and state that key SSCM inter-organizational practices include codes of conduct $([34,35])$, supplier certifications [36], supplier training and education [37], investments in emission reduction technology, changes in production processes, product design, and more efficient use of raw materials [33]. 
Precise definition, however, remains elusive. Sustainable Supply Chains (SSCs) could be defined as those that are capable of significantly reducing the use of materials, energy, and other resources, while achieving their economic objectives with a positive overall impact on society [38-40]. Thus, SSCs are able to find eco-efficient solutions through better management of the supply chains [23,41,42]. Nevertheless, there is not yet a generally accepted definition of either GrSCM or SSCM; authors like Ahi and Searcy ([14], p. 340) affirmed that "areas of GrSCM and SSCM are still relatively new, and a diversity of perspectives in terms of definitions is useful. However, as research on the integration of sustainability into SCM continues to expand, it will become increasingly important to address the inconsistencies in the various definitions of GrSCM and SSCM".

\subsection{Relationship within Participants/Echelons in the SSCM}

One of the key areas within SSCM, that has received particular attention by the scholars in the field, is the relationship between the focal company and its suppliers, as well as within the suppliers themselves, and how SSCM is contingent on these relationships.

As discussed above, Roehrich et al. [18] focus on Green Supplier Selection (GSS) from a first-tier supplier's perspective, as well as on the importance of second-tier suppliers' value internalization and approaches to achieve it.

Some companies strive to identify and apply a new supply network structure [43], trying to attain a more trustful and reliable supplier base and thus to increase sustainability along the supply chain [44]. Even though many studies are implicitly based on the reactivecooperative supplier-buyer model, other authors such as Zimon et al. [45] propose a more proactive approach for managing supplier relations (engagement instead of merely control or supplier guardianship).

\subsection{Measurement in the SSCM}

Precise, generally agreed-upon measurement stands out as a key challenge in SSCM. As in other business areas, SSCM scholars and practitioners keenly look for approaches that would allow them to develop and apply specific objectives within SSCM, as well as precise indicators to measure them.

According to Beske-Janssen et al. [46], the accurate measurement of sustainability indicators would help to create transparency in SCs and promote innovation in SSCs; they consider, however, that the literature on performance management within SSCM is still scarce due to reasons such as the difficulty of establishing clear, measurable, and comparable measurement parameters. Along similar lines, Grosvold et al. ([32], page 295) highlight how SSC performance depends upon the interaction between SSC management and SSC measurement, while at the same time acknowledging that, with the noteworthy exception of Hoejmose et al. [47], SSCM literature has paid little attention to the measurement of sustainability.

Roehrich et al. [18], while analyzing GrSCM, state that it is often hard to precisely measure environmental factors, and even those measurements that do exist are often kept private by the incumbents; in fact, in their study of Green Supplier Selection (GSS), they recognize (page 492) that focal companies are often not given direct access to their suppliers' environmental management systems, thus leading to a lack of transparency on environmental issues.

In spite of these challenges, the quest for effective measurements has continued apace. Some scholars have developed multi-criteria tools, encompassing qualitative and quantitative measurements, to support supplier selection decisions $[48,49]$. Furthermore, various approaches have been developed in recent years to manage the measurement of SSCM based on tools such as sustainable balance scorecard [33], life-cycle assessment [50], and product carbon footprint [51]. 


\subsection{Innovation in SSCM, SOI, SOI Practices, SOI Shortcomings}

Building on the abovementioned body of knowledge on the GrSCM/SSCM approaches (critically encompassing the analysis of the interaction within SC echelons/participants) and on the challenging attempts to precisely measure their results, researchers turned their attention to the role played in this process by innovation, and more specifically, Sustainability-Oriented Innovation (SOI).

Innovation, and specifically innovation in the SC, is considered by some authors as key for achieving a competitive advantage [52]. Some early studies focused on technologybased and product design innovation. Lambert et al. [53] indicate that the key to collaborative innovation in the supply chain is to integrate information from various sources using information technology. Sezn and Çankaya [54] show that technological innovation can help promote the sustainable development of companies. Mangun and Thruston [55] argue that coordinated innovation in product design reduces the total life cycle impact on the environment; innovation in greener processes, specifically, has a positive effect on the company's sustainable development performance. Pagell and $\mathrm{Wu}$ [56] introduce the concepts of "innovation and the design of capabilities" within the framework of sustainable supply chain management and emphasize the relevance of innovation in organizations seeking to implement SSCM.

Given the multi-actor nature of SCs, innovation focusing on the interaction among participants and/or the design of processes is particularly relevant. Thus, innovations must extend beyond individual companies and include the entire supply chain. Malone and Crowston [57] believe that companies in supply chains need to establish appropriate collaborative innovation to maintain consistency when making decisions.

The convergence of the study of the role of innovation in SCs and the focus on sustainability led to the development of the concept of Sustainability-Oriented Innovation (SOI), and more specifically, SOI within the SSCM [58,59]. In this line of thought, SOI can be defined as the introduction of new or modified processes, techniques, systems, organizations, and products in order to minimize environmental and social impact [60,61], while emphasizing that these innovations must provide a similar or superior value, with a better economic, social, and environmental result [58,62].

Gao et al. [63] carried out a conceptual analysis of the three interlinked concepts of innovation, sustainability, and supply chain that further developed previous studies, thus shedding additional light on the link between innovation and SSCM. Their analysis built on the existing studies of Supply Chain Innovation (SCI), defining SCI as a change in the SC stemming from "both radical and non-radical changes" in the product, the processes, the technology, the marketing, the resources, and/or the organization. By specifically focusing on sustainability, they combined the concepts of SSCM, SCI, and SOI into what they termed as Sustainable Supply Chain through Innovation Management (SSCIM). They define SSCIM as the innovation-driven introduction of changes that affect the entire supply chain, and create value for its stakeholders by attaining balanced, positive results in all three economic, environmental, and social perspectives. After publication of their highly relevant research, numerous research studies have focused on SSCIM, as highlighted in the paper published by Tebaldi et al. [30], where they emphasize that the studies published regarding SSCIM, in the 2011-2017 period, have increased six-fold.

The SOI and SSCIM concepts led, in turn, to the study by various authors of the role of SOI practices [59,64-66]. Authors such as Kusi-Sarpong et al. [61], Gupta and Barua [67], and Gupta et al. [68] argue that achieving the sustainability objectives in organizations and supply chains requires the adoption of SOI practices. Sustainable innovation can be considered as the introduction of new practices in the organization's processes with the purpose of adding value or mitigating possible damage in the supply chain and/or the stakeholders, as well as improving the competitive position of the firm or supply chain. Gao et al. [63] analyze the challenges posed by mobile phones, worldwide and particularly in China, where $70 \%$ of mobile phone owners change them every 18 months. Recycling is not actually living up to expectations (thus the coinage of the term "e-waste"), and 
is currently incapable of handling the resulting huge amount of waste. These authors consider that the solution lies not in individual companies (manufacturers or phone sellers), but in changes to be introduced in the entire SC. Sustainable innovation should minimize the volume of waste, compared to the current situation, thus making it manageable. They stated that such sustainable innovation in the SC will require changes in the product, in the processes of the focal company, and in the processes of the rest of the SC members; from after-sales service to suppliers, which will contribute to the design and manufacturing of the components of these devices. Other authors such as de Vargas-Mores et al. [65] consider that SOI should include the use of renewable energy, reverse logistics, eco-efficiency, and the involvement of the entire supply chain. They analyze the impact of the SOI practices in the sustainability of the SC of a company that develops and manufactures plastics in Brazil, trying to apply SOI practices in order to minimize the environmental impact of the manufacturing of the so-called "green plastics". Some authors also highlight that companies apply risk-mitigation practices that could be assimilated to SOI practices [69]. These risk-mitigation practices can be linked to the concept of resilience, and various approaches have been proposed to select the most suitable set of innovation-based riskmitigation initiatives to enhance the firm's "readiness capacity" [70].

Nevertheless, SOI continues to be an insufficiently studied area, plagued by various shortcomings. Authors like Doherty et al. [71] focused on the little attention that had been paid to SOI so far, and the concept's limitations. Following Adams et al. [72], there are several deficiencies that could be summarized as: (i) they consider that existing literature is still not clear regarding what sustainability really is and how to achieve it, since a great variety of conceptualizations have appeared and a certain level of confusion has been generated, as illustrated by the use of a number of labels including corporate social responsibility, green-, eco-, ecological innovation, and responsible innovation [73-75], (ii) some authors have tried to define sustainability in a dichotomous manner (sustainable vs. non-sustainable), instead of viewing SOI as a dynamic process that develops over time, (iii) these authors consider that, with some notable exceptions such as Klewitz and Hansen [76], previous studies overstate the social aspect of SOI, (iv) numerous studies do not include actual experiences of SOI applications, often being based more on theoretical models than on practical experiences.

\section{Model-Based Analysis of Innovation in Sustainable Supply Chains, Research Gap, Research Questions, Baseline Model}

As previously discussed, the integration of the sustainability perspective into SCM resulted in the development of the SSCM/GrSCM research and practical application domains. Increasing awareness of the key role played in this arena by innovation led to a research stream in SOI in SSCM, and specifically in SOI practice. In an attempt to organize knowledge in this field in a coherent structure that lends itself to application by practitioners, and facilitates the study of eventual interrelationships within SOI practices, various authors have proposed models or frameworks that constitute the springboard for this paper. Several researchers have proposed sustainable management frameworks $[77,78]$ and have emphasized the importance of innovation in the sustainable supply chain $[63,64]$. Fewer studies, however, have SC framework models specifically aimed at SOI practices.

Adams at al. [72] tried to develop a synthesized conceptual framework on which SOI practices and processes could be mapped. Yang and Wang $[79,80]$ have studied how textile companies in China have developed SOI practices in their SCs to alleviate the adverse effects of their activity. These companies aim to reduce their impact in terms of air pollution, water pollution, and other damaging impacts on their industrial activity. These authors have developed and proposed a model that organizes SOI practices along several dimensions. Their model contemplates three SOI practice dimensions (economic dimension, social dimension, and environmental dimension) and seventeen sub-dimensions potentially applicable for the structuring and classification of sustainable innovation in SCs. According to their analysis, in that industry, economic considerations were the most relevant. This 
paper's authors, however, consider that their analysis is very specific for that particular industry situation and context [81].

Among the various models and frameworks proposed in the literature that provide a useful structure for the analysis and classification of SOI practices, the authors of this paper have decided to use, as a starting point, the highly cited framework proposed by KusiSarpong et al. [61]. They propose a SOI framework for investigating SSCs in manufacturing companies (thus, in line with the focus of this paper, the unit of analysis is clearly the entire SC, rather than just the focal company, or the dyad focal company first-tier supplier), differentiating the economic, environmental, and social dimensions. Their research is based on a 5-case field study of Indian companies in three manufacturing sectors (automobile, electric components, plastics) that shared a commitment to apply innovation to lessen their environmental impact. After highlighting the generally accepted key role of SOI in SSCM, they stress that existing literature fails to provide deep insights into sustainable innovation management in SSCM implementation, thus justifying the need for additional applied studies.

Therefore, the literature review described in the previous sections highlighted the theoretical and practical importance of analyzing SOI practices, as well as the existence of a rapidly growing body of knowledge. The review of the attempts to structure this knowledge also revealed, however, a research gap. Existing models were mainly descriptive/classificatory, rather than being model-based, aimed at establishing the interdependence between their components and thus actionable. They focused on establishing dimensions and sub-dimensions that facilitated orderly classification of SOI practices. However, each of these SOI practices was usually studied in isolation, while their interrelationships, potential dependences, or mutual reinforcement potential received less attention. Furthermore, their contingent nature, or adhocratic dependence on the main or strategic traits of the adopting company, was often not analyzed. To the best of the author's knowledge, no published structured model provided the direct linkage to actual industry practices combined with the focus on applicability that would enable its actual application by practitioners for innovation-based sustainability advancement practices such as benchmarking or self-appraising.

This realization led to the identification of three research questions:

RQ1: To which extent do SOI practices from SSCM leaders actually match published frameworks/models?

RQ2: Are published frameworks/models overlooking key ingredients or relationships?

RQ3: How can companies tailor their model-based SOI SSCM to their strategic specificities/idiosyncrasy (contingency)

In order to tackle these research questions, the authors decided to draw on the theoretical underpinnings developed in the recent research streams and combine them into an initial baseline model. This initial model could then be further developed thorough its in-depth application to a leading company, thus contributing to bridge the identified research gap.

As discussed above, the framework proposed by Kusi-Sarpong et al. [61] was selected as a starting point for the development of this initial baseline model. These authors comprehensively reviewed the sustainable supply chain management and green/sustainable innovation management literature. Based on that review, they populated a preliminary SOI practices framework encompassing four broad dimensions and 25 sub-dimensions. Through testing and interviews, they arrived at the four dimensions, 20 sub-dimensions framework they propose; subsequently, its constituent sub-dimensions were prioritized by applying a "best-worst" multi-criteria model. As previously discussed, the framework proposed by these authors is mainly descriptive/classificatory, focused on establishing dimensions and sub-dimensions that facilitated orderly classification of SOI practices.

Based on this framework, the authors of this paper have instantiated a simpler, more easily quantifiable baseline model, depicted in Table 1, encompassing four sub-dimensions for each of the three broad dimensions, which, according to their previous studies of SSCM, 
could lend itself more readily to application in actual companies. Further detail on the supporting literature for each sub-dimension can be found in Kusi-Sarpong et al. [61], where a list of bibliographic references for each sub-dimension is provided.

Table 1. SSC SOI practices baseline model. Source: own elaboration, based in Kusi-Sarpong et al. [61].

\begin{tabular}{|c|c|c|}
\hline Dimensions & Subdimensions & Description \\
\hline \multirow{4}{*}{ Economics } & E1/Sustainable cost reduction & $\begin{array}{l}\text { Organization's ability to reduce product cost through } \\
\text { sustainable innovation practices }\end{array}$ \\
\hline & $\begin{array}{l}\text { E2/Enhanced sustainability value } \\
\text { to customers }\end{array}$ & $\begin{array}{l}\text { Provision of greater value to customer by either reducing } \\
\text { price or enhancing product functionalities }\end{array}$ \\
\hline & $\begin{array}{l}\text { E3/Investment in R\&D for } \\
\text { sustainable products }\end{array}$ & $\begin{array}{l}\text { Provision of financial resources to support sustainable } \\
\text { products development }\end{array}$ \\
\hline & $\begin{array}{l}\text { E4/Designing sustainable products to reduce } \\
\text { material consumption }\end{array}$ & $\begin{array}{l}\text { Organization practices to design and deliver products } \\
\text { with lower use of resources }\end{array}$ \\
\hline \multirow{4}{*}{ Environmental } & $\begin{array}{c}\text { A1/Inter- and } \\
\text { intra-organization collaboration }\end{array}$ & $\begin{array}{l}\text { Collaboration between different functions } \\
\text { and/or organizations }\end{array}$ \\
\hline & A2/Sustainable supply chain practices & $\begin{array}{l}\text { Organization capabilities to package, label, and transport } \\
\text { products in an environmentally friendly manner }\end{array}$ \\
\hline & $\begin{array}{l}\text { A3/Environment management commitment } \\
\text { and initiatives }\end{array}$ & Adoption of environment policies and standards \\
\hline & $\begin{array}{l}\text { A4/Conducting regular } \\
\text { environmental audits }\end{array}$ & $\begin{array}{l}\text { Regular audits to ensure environmental } \\
\text { standards compliance }\end{array}$ \\
\hline \multirow{4}{*}{ Social } & $\begin{array}{l}\text { S1/Quick response to customers and market } \\
\text { demand for sustainable products }\end{array}$ & $\begin{array}{l}\text { Organization responsiveness capability to market demand } \\
\text { (and awareness of sustainable relevance) }\end{array}$ \\
\hline & S2/ Corporate social responsibility initiatives & $\begin{array}{c}\text { Adoption of general ethics policies towards social and } \\
\text { environmental issues }\end{array}$ \\
\hline & S3/Cultural, social values, and norms & Organization values and beliefs in relation to society \\
\hline & $\begin{array}{l}\text { S4/Occupational health, safety, and } \\
\text { employees rights }\end{array}$ & Organization efforts to improve employees conditions \\
\hline
\end{tabular}

As described in the following sections, this baseline model is then applied in an in-depth case study involving a leading focal company and the various echelons of its supply chain.

\section{Objectives and Research Methodology}

\subsection{Objectives and Methodology}

As discussed in previous sections, the review of the published research on the role of Sustainability-Oriented Innovation (SOI) in SSCM highlighted its critical relevancy, and illustrated a number of instrumental SOI practices, such as green supplier selection, codes of conduct, or third-party certification. It also revealed a research gap, namely a scarcity of structured, actionable models/frameworks, directly linked to actual industry practice, that go beyond a descriptive/classificatory approach to delve into the interrelationships between the SOI practices as well as their contingency on the adopting company's traits. This led to the identification of three research questions, revolving around the relationship between published models and actual practice, eventual missing ingredients or relationships, and their contingency on the adopting company's traits.

To tackle these, the authors adopted a modified version of a widely referenced descriptive/classificatory framework as a starting point, and set the following specific objectives for this study (which belongs to a long-standing research line on SSCM practices, focused on making proposals for improving practices, potentially with cross-industry applicability): 
1. Validate, or further develop if needed, the proposed classificatory framework through practical application in an in-depth case study. The aims were both to establish whether the actual SOI practices applied in a leading SSC appropriately fit into this structure, and whether such a leading SSC did apply relevant SOI practices in all the dimensions/sub-dimensions (thus tackling Research Question RQ1).

2. Increase the structural coherence and explicative capacity of the model (thus transcending the descriptive/additive nature of the baseline framework) by complementing it with previously overlooked key components, and by prodding into the interrelationships between its initial dimensions and the new components (thus tackling RQ2).

3. Explore the contingency relationship between the resulting model and the core traits of the focal company (thus tackling RQ3, and illustrating the need for careful analysis in the last objective).

4. Create a tentative benchmark against which less-developed SSCIM implementations could measure themselves and explore the model's usefulness to develop innovationbased improvement plans as a self-appraisal tool, while being fully aware of the need to specifically tailor certain model elements to the adopting company's characteristics, due to their contingency relationship.

In order to achieve these objectives, the authors designed an abductive research project based on an in-depth case study of the multi-echelon supply chain of a leading Spanish retailer. Tebaldi et al. [30] have studied, based on a systematic literature review of journal articles and diverse publication sources for the 2015-2017 period, the type of methodology applied to carry out studies related to sustainability, and specifically concerning the relationship between SSC and innovation. They conclude, in line with previous studies developed by Seuring and Muller [12], that "case study" was the second most prevalent research method, exceeded only by empirical research.

The case study method selected for this paper is, according to Eisenhardt [82], Voss et al. [83], and Seuring and Müller [12], very suitable for issues related to strategic management, such as sustainability. Yin [84] suggests the use of case study analysis when boundaries between the context and the phenomenon to observe are not obvious. Case studies have been gradually recognized, despite some criticism, as an appropriate approach "to address contemporary organizational problems and establish credibility" $[85,86]$.

As previously discussed, the coding system used by the authors for the analysis of the collected data was based on the three broad dimensions and 12 sub-dimensions of the baseline model. Whenever a SOI practice was identified, it was classified in the dimension/sub-dimension that provided the best fit; then, one or several significant resulting SOI instances or examples were documented, and, whenever possible, supporting quantitative data were collected to illustrate the level of structural commitment and resources devoted to this SOI practice. As discussed in the following sections, those SOI practices that defied classification in the baseline model were carefully combed, in line with Research Question 2 and Objective 2, to determine if they could be considered a missing or overlooked key component.

\subsection{Selection of the Case Study}

The multi-echelon supply chain of a leading Spanish retailer was chosen for the indepth case study. The reasons for the selection of that particular SC include: (i) size and international relevancy within the sector (and relevance of the retail sector for the SSCM, as discussed below), (ii) the focal company is also widely recognized as a market leader both in innovation and in sustainability, as well as in related areas such as TQM, (iii) this study is part of a long-standing research line on SSCM practices that has allowed the authors to develop an in-depth knowledge of this SC, (iv) data availability and access, particularly sustainability-specific data (sustainability and environmental reports, etc.) triangulated with other published data sources (e.g., annual reports, complementary secondary data). 
Its supermarket chain sells both fresh food products and other consumer products, with heavy emphasis on its own distributor brands, with a yearly turnover of more than 25 billion euros and around one hundred thousand employees in 2020. Further data on this SC are provided in the following sections.

\subsection{European Retail Sector and Relevancy within SSCM}

The SC analyzed here corresponds to one of the top 30 retailers in Europe (Table 2), including both brick and mortar and online businesses. Although these top retailers have achieved a high turnover (ranging from $€ 12$ billion to $€ 104$ billion), their EBITDA growth has slumped in recent years, due to higher market price pressure [87]. Table 2 includes the 30 top retailers in Europe; the case being analyzed is one of the three Spanish companies included in this ranking.

Table 2. Top 30 retailers in Europe by country of origin. Source: authors' own elaboration.

\begin{tabular}{|c|c|c|c|}
\hline Germany & 8 companies & Netherlands & 2 companies \\
\hline France & 7 companies & Sweden & 2 companies \\
\hline UK & 4 companies & USA & 1 company \\
\hline Spain & 3 companies & Others & 3 companies \\
\hline
\end{tabular}

Companies within this sector have to fight for survival through improvements in their business models, with a clear trend towards the adoption of online models and the introduction of innovations that enhance the SSCM. Thus, some authors [88,89] have identified practices applicable by retailers in order to improve their businesses, through the implementation of mechanisms that could be considered SC SOIs. In order to improve supply chain sustainability, retailers could focus on specific links within their supply chain: e.g., they can increase the pressure on their suppliers to implement further sustainability practices, or encourage consumer behavior pattern changes [90,91]. However, according to some authors, real sustainability breakthroughs are more likely when a set of practices are implemented both in the focal company (retailer) and in the whole SC network [92]. This SC transformation might lead not only to a better environmental and social compromise, but also to a noticeable increase in business volume and profitability, as suggested by a recent study developed by consultancy firms [93].

There are ample opportunities for improvement in sustainable innovation in the European retail industry; a recent study published by the European Union [94] shows that, in recent years, $\mathrm{CO}_{2}$ emissions from the retail sector accounted for around $4 \%$ of total emissions in the European Union (EU) countries. One of the elements contributing to this level of emissions is the high energy intensity level in shops and stores, as reported by Ferreira et al. [95]. Regarding corporate social responsibility, generally speaking, retailers do not achieve high scores $[96,97]$ in these social practices since the type of services they provide and the business models that have been applied for decades usually involve high employee turnover and a high percentage of temporary contracts.

\section{Results and Discussion}

The abductive research methodology chosen involves applying the proposed descriptive/classificatory SSC SOI practices baseline model (Table 1) in the multi-echelon SC of the chosen leading Spanish retailer.

The first step was to identify relevant SOI practices in this SC, and to attempt to match them to the closest category (dimension/sub-dimension in the baseline model). For every SOI practice identified, resulting SOI instances or examples were gathered. An attempt was then made to compile ancillary data that would help to gauge, or ideally quantify, the degree of implication of the SC in that SOI practice, e.g., by measuring the infrastructure involved, resource assignment, or uptake levels. In subsequent steps, identified SOI practices that did not seem to fit would be subject of further analysis. Table 3 shows the results found. 
Table 3. SSC SOI practices populated model. Source: own elaboration.

\begin{tabular}{cc}
\hline Dimension & Sub-Dimension \\
\hline & \\
& E1/Sustainable cost-reduction \\
(stakeholder involved: $C, S, O)$
\end{tabular}

(stakeholder involved: C, S, O)

E2/Enhanced sustainability value to customers

(stakeholder involved: C, S, SO)

\section{SOI Practices/SOI Examples/Supporting Quantitative Data}

Permanent focus on sustainable innovation that could bring value to customers at the lowest feasible cost.

Example:

New tool to improve inventory management that increase stock accuracy.

Focus on supply chain integration to improve sustainability innovation in processes that jointly apply lean tools and waste reduction principles. Example:

Programs to generate supplier's long-term engagement through promotion of lean tools implementation by suppliers.

Food assurance control (no supplier error on quality allowed). Food safety as key

SC priority, exceeding legal requirements. Zero defects in food safety as guiding objective in production and distribution processes. Examples:

Joint project with Spain's National Research Center (CSIC) and five tier-1 suppliers to improve food safety in fresh fish product.

Scales in cash register points. Clients no longer have to weigh and label fruit and vegetable products while and facilitating the employee's activities.

Corporate "food safety and quality management system" that exhaustively controls each step in the SC, from the origin of the raw materials to the final customer.

Examples:

Since 2004, an independent panel of reputed professionals provides technical guidance on food security to the focal company's staff.

Implementation of an internal system of simulacrums/drills to enhance food security.

Sustainability innovation considered as a strategic corporate asset; customers involved in innovation projects. Most of them linked to sustainability innovation. Examples:

Added sugar-free yoghurts, resulting in a healthier and pollution-free product. Compact disinfectant tablets to replace traditional bleach, with a format that reduces safety hazards, transport, and storage. E3/Investment in R\&D for
sustainable products (stakeholder involved: C, E, S, SO, O)

Focal company has developed an entity ("Angel") to invest in entrepreneurship projects focused on SC sustainable innovations. Selected entrepreneurs are offered a TQM-based management model aligned with the company's philosophy, as well as the required infrastructure, to support their own sustainable innovation research.

Supporting quantitative data:

Nineteen innovation centers and 9000 customers involved in innovation per year.

\section{Products are designed and re-designed to reduce usage of materials.} Examples:

More efficient freezers, in terms of consumption and isolation. Includes LED-based illumination that lowers both energy consumption and heat emission.

Square oil bottles redesign that saves space in storage and transportation. Improvements in glass jars manufacturing processes, thus reducing weight, raw materials consumption, and waste.

Reusable transportation plastic boxes that are sanitized in the logistic units and returned to suppliers.

Elimination of micro-plastics in all cosmetics and personal care products.

E4/Design sustainable products to reduce material consumption (stakeholder involved: C, E, S, O)
Focus on Circular Economy, achieving significant reduction of its environmental footprint, as compared to its competitors, through numerous eco-efficient initiatives. Examples:

New shopping bags now offered to its customers that are reusable and made with $70 \%$ recycled plastic. Over 3000 tons of plastic per year used for their manufacturing come from the packaging that is recovered at the stores. This flow is managed through its own reverse logistic process to an authorized recycler that transforms the material into new plastic raw material that is then used by a tier-1 supplier (Plasbel) to manufacture new bags. Supporting quantitative data:

Separation and either reuse or recycling of $76 \%$ of the waste generated at its stores. Abovementioned 3000 tons of plastic per year recovered from packaging and reused in manufacturing. 
Table 3. Cont.

\begin{tabular}{|c|c|c|}
\hline Dimension & Sub-Dimension & SOI Practices/SOI Examples/Supporting Quantitative Data \\
\hline \multirow{4}{*}{ Environmental } & $\begin{array}{l}\text { A1/Inter- and } \\
\text { intra-organization collaboration } \\
\text { (stakeholder involved: E, S) }\end{array}$ & $\begin{array}{l}\text { Total Quality (innovation) methodology applied in supplier relationships. } \\
\text { Examples: } \\
\text { Joint innovation collaboration along the supply chain. } \\
\text { Supplier process integration tool designed by focal company. } \\
\text { Supporting quantitative data: } \\
\text { Collaboration with } 1400 \text { suppliers. }\end{array}$ \\
\hline & $\begin{array}{l}\text { A2/Sustainable supply chain practices } \\
\text { (stakeholder involved: } C, E, S)\end{array}$ & $\begin{array}{l}\text { Focus on sustainability practices along the supply chain. } \\
\text { Examples: } \\
\text { Pilot project in two major cities (Valencia and Barcelona) to improve the } \\
\text { environmental sustainability of its logistics for the online channel. } \\
\text { Special transport network designed to reduce movements. } \\
\text { Use of mega-trailers/bi-trailers to increase transport capacity per truck. } \\
\text { "Noiseless urban unloading" practice to avoid annoyances to neighbors in } \\
\text { city locations. } \\
\text { Electric vans for last mile distribution in online shopping. } \\
\text { Requirement of "sustainable fishing" certificate for all its fish products. } \\
\text { Employee access to an internal computer application aimed at sharing examples } \\
\text { of good practices to improve process sustainability. }\end{array}$ \\
\hline & $\begin{array}{l}\text { A3/Environmental management } \\
\text { commitment and initiatives } \\
\text { (stakeholder involved: } \mathrm{S}, \mathrm{SO}, \mathrm{O} \text { ) }\end{array}$ & $\begin{array}{l}\text { New energy-efficient shop model. } \\
\text { Examples: } \\
\text { Exhaustive plan to detect and prevent refrigerating gas leaks. } \\
\text { product quality. } \\
\text { Real-time monitoring of the store's equipment and infrastructure to guarantee } \\
\text { Vegetation rooftops at stores as } \mathrm{CO}_{2} \text { sinks. } \\
\text { facilitate recycling and Circular Economy. } \\
\text { Electric vehicle recharge parking slots. } \\
\text { Promotion of proximity products. } \\
\text { In } 2019 \text {, through a business accelerator, it started an open-innovation project (the } \\
\text { Lanzadera Project) to support its SSC. It focuses on five challenges: plastic } \\
\text { reduction/elimination, energy savings, waste management, healthy products, and } \\
\text { last mile logistics optimization. The project is supported by Revoolt, a company } \\
\text { specialized in last mile logistics for food products, with a zero-emissions model } \\
\text { and a strategy focused on developing the forthcoming sustainable logistic strategy. } \\
\text { Supporting quantitative data: } \\
\text { Energy-efficient shop model applied in } 1700 \text { shops; } 40 \% \text { less energy. } \\
\text { Nine-hundred electric vehicle recharge parking slots planned in the new } \\
\text { sustainable stores. }\end{array}$ \\
\hline & $\begin{array}{l}\text { A4/Conducting regular } \\
\text { environmental audits } \\
\text { (stakeholder involved: E, S) }\end{array}$ & $\begin{array}{l}\text { Audits used as a SC supply chain improvement tool within a structured plan led } \\
\text { by the focal company. } \\
\text { Examples: } \\
\text { Audits by external specialized organizations, also including suppliers (IFS and } \\
\text { BRC standards). } \\
\text { Supporting quantitative data: } \\
\text { In } 2019,8405 \text { process audits in the focal company and its suppliers, } 330 \text { controls in } \\
\text { the logistic centers, and } 1743 \text { suppliers evaluated. }\end{array}$ \\
\hline \multirow[b]{2}{*}{ Social } & $\begin{array}{l}\text { S1/Quick response to customers and } \\
\text { market demand for sustainable products } \\
\text { (stakeholder involved: C, E, S, SO, O) }\end{array}$ & $\begin{array}{l}\text { "Customer voice" internalized as an engine for sustainability innovation. } \\
\text { Examples: } \\
\text { Co-innovation/customer involvement; employees act as the "customer voice in } \\
\text { the organization". } \\
\text { Extensive training to get employees involved in sustainability innovation practices } \\
\text { (bottom up). Recognizing employees' involvement on these practices } \\
\text { (including bonus). }\end{array}$ \\
\hline & $\begin{array}{c}\text { S2/Corporate social } \\
\text { responsibility initiatives } \\
\text { (stakeholder involved: E, S, SO) }\end{array}$ & $\begin{array}{l}\text { Social responsibility impregnated within focal organization. } \\
\text { Examples: } \\
\text { Extensive cooperation with NPOs. } \\
\text { Social innovation initiative at the stores, chartering foundations and associations } \\
\text { of persons with various levels of disability to prepare murals for the decoration of } \\
\text { its fish and meat sections (new stores). } \\
\text { Supporting quantitative data: } \\
100 \% \text { suppliers certified "animal welfare" by } 2021 .\end{array}$ \\
\hline
\end{tabular}


Table 3. Cont.

\begin{tabular}{|c|c|c|}
\hline Dimension & Sub-Dimension & SOI Practices/SOI Examples/Supporting Quantitative Data \\
\hline & $\begin{array}{l}\text { S3/Cultural, social values and norms } \\
\text { (stakeholder involved: C, E, S) }\end{array}$ & $\begin{array}{l}\text { Strong "stakeholder's relevancy" recognition throughout the focal company's } \\
\text { organization, with focus on continuous supply chain innovation. } \\
\text { Example: } \\
\text { Development of strategies to avoid food waste throughout the SC, involving } \\
\text { inappropriate purchasing, management, handling, and consumption practices. }\end{array}$ \\
\hline & $\begin{array}{l}\text { S4/Occupational health, safety and } \\
\text { employee rights } \\
\text { (stakeholder involved: E) }\end{array}$ & $\begin{array}{l}\text { People are treated as the key assets. } \\
\text { Examples: } \\
\text { HHRR practices promoting permanent contracts, despite the Spanish retail } \\
\text { sector's general policy or resorting to temporary (fixed-term) contracts. } \\
\text { Cash bonus for all focal company employees, subject to the achievement of SSC } \\
\text { innovation goals. } \\
\text { In 2007, it opened its first intelligent, fully automated warehouse. It prevents any } \\
\text { overexertion by employees, thus reducing the risk of occupational accidents while } \\
\text { increasing the efficiency. } \\
\text { Supporting quantitative data: } \\
\text { Over } 90 \% \text { of the workforce on permanent contracts in } 2020 . \\
\text { Minimum entry salary } 20 \% \text { above market average. }\end{array}$ \\
\hline
\end{tabular}

Note: Customer: C, Employee: E, Supplier: S, Society: SO, Capital: O.

The focal company being analyzed is a major retailing business (food, personal care products, and home cleaning products). Its retail network involves more than 1700 supermarkets and 100,000 employees in Spain and Portugal. Since its foundation, it has been deeply committed to the practices that promote sustainable innovation in the SC, along with transparency. Its strategy incorporates the United Nation's Sustainable Development Objectives [98-100]. As reflected in its 2019 annual report, this approach is systematically applied to all the company's processes, and extended throughout the supply chains of its major suppliers per product (approx. 1400 tier-1 suppliers). This integrated sustainability must fulfill the requirements of the major stakeholders identified in the company's strategy (customers, employees, suppliers, society, and owners/capital).

As for the relationship between these stakeholders and the SOI practices being studied, Table 3 specifies, for each sub-dimension, the key strategic stakeholders (C, E, S, SO (Society), O) involved in the SOI practices within that sub-dimension. It is, however, worth emphasizing the overriding focus on meeting the requirements of one specific stakeholder: the customers. Each new product must undergo extensive review and testing before being offered to its customers. Furthermore, products belonging to its own brand (the distributor brand) are required to outperform all competing products not only in terms of attributes that the customer can readily appreciate (e.g., taste, quality, etc.), but also in traits such as SC sustainability that are apparently unobservable by the customer. Thus, aspects such as complying with animal welfare practices are not directly visible by the customers, however, the company deems them particularly relevant for their long-term relationship.

In some instances, sets of SOI practices are grouped together in a program or "concept", because they mutually reinforce each other and/or to facilitate their promotion/advancement and the gauging of their combined likely impact. It is worth highlighting the "sustainable store" concept, which is an evolutionary model that the company expects to continue developing overtime, aimed at reducing up to $40 \%$ the illumination and refrigeration energy consumption, as compared with a traditional store. It encompasses such practices as the above-mentioned (E4) LED-based illumination, special doors to isolate the freezers area, applying floating condensation to improve refrigerating efficiency, automated air conditioning regulated according to the external temperatures, or overpressure and access halls to prevent air currents. New stores utilize refrigerating equipment that use gases with lower greenhouse impact, and sub-critical systems that reduce the usage of fluorinated gases. The company estimates that the application of this concept, and the corresponding set of SOI practices, is a key factor in the achievements in emissions shown in Table 4. 
Table 4. Evolution of emissions. Source: own elaboration based on published data from the focal company.

\begin{tabular}{cccc}
\hline Environmental Management & $\mathbf{2 0 1 7}$ & $\mathbf{2 0 1 8}$ & $\mathbf{2 0 1 9}$ \\
\hline Total emissions * $^{*}$ & 45.38 & 44.58 & 38.86 \\
Direct emissions * $^{*}$ & 14.13 & 13.02 & 6.93 \\
Emissions due to energy consumption * & 17.98 & 15.12 & 14.79 \\
Emissions due to transportation of goods * & 13.27 & 16.44 & 17.16 \\
Emission savings in CO $\mathrm{CO}_{2}$ equivalents & & 37 & 200 \\
(Thousands of tons) & - & & \\
\hline
\end{tabular}

$\mathrm{CO}_{2}$ equivalent emissions. In $\mathrm{Kg}$ per cubic meter of product sold.

Data in this table reflect the focal company processes, including transportation from the logistic centers to the stores, estimated by the company based on the protocol commonly used to estimate emissions of Green House Gases (GHG), jointly developed by the World Resources Institute (WRI) and the World Business Council for Sustainable Development (WBCSD). Data for 2018 and 2019 are extracted from the 2019 Annual Report ([100], pages 83-84), while data for 2017 come from its 2017-2018 Environmental Report ([101], page 37). Overall $\mathrm{CO}_{2}$ equivalent emissions (per cubic meter of product sold) noticeably fell during the period. Furthermore, the reduction is entirely attributable to the processes directly affected by the SOI practices included in the "sustainable store" concept, namely direct emissions and emissions due to energy consumption; the emissions due to transportation of goods, unrelated to the "sustainable store" concept, actually increased.

With regard to the first objective (and the first Research Question), results of the in-depth case analysis showed that, for the specific leading SC under study, relevant SOI practices were actually identified for all dimensions and sub-dimensions of the proposed model. For each SOI practice, significant resulting SOI instances or examples were identified. In some cases, supporting quantitative data provided an illustrative indication of the level of structural commitment and resources devoted to this SOI practice (e.g., 1743 suppliers undergone audits for SC improvement) or to the specific SOI instance (e.g., 3000 tons/year of plastic recovered from packaging and reused in their manufacturing). This suggests that the proposed descriptive/classificatory baseline model is indeed useful for the structuring and comprehensive reviewing of a company's SOI practices, and is grounded on actual practice by SSCM leaders.

However, with regard to the second objective (and the second Research Question), the in-depth analysis of the supply chain of this retailer revealed that, beyond the SOI practices that neatly fitted into the descriptive/classificatory, additive, dimension-oriented baseline model (Table 1), three additional SOI practices were identified. They did not conceptually fit in the baseline model but were quite relevant in the analyzed supply chain:

(i) Integral supply chain approach, including farmers (over 16,200 different farmers) and fishermen (over 12,000). This is fully aligned with a long-term strategic objective of developing a "sustainable innovation SC in the Primary Sector" [100]. This approach is also related with the supply chain engagement capabilities observed and discussed by some authors [102]. It is aimed at joining efforts and sharing knowledge at each step of the SC, thus generating efficiencies through shared innovation. This practice encompasses elements such as: (a) providing stability and visibility of the whole SC commitment with SC members that belong to the highly unpredictable primary sector, (b) innovation in productivity-enhancing practices, (c) integrated planning of the overall SC, from the primary sector supplier to the focal company, c) continuous review of the sustainable innovation plans and programs. Illustrative examples of actions aimed at these goals include: collaboration with the supplier Totaler Escuris, and the International Seafood Sustainability Foundation (ISSF) to ensure that $100 \%$ of the canned tuna sold under the distributor brand come from sustainable, responsible fisheries; and the joint research project undertaken with Spain's national research center (CSIC) to prevent fish parasites. As a guide to understand the scale of these 
endeavours, this supply chain manages a volume of 20,187 million euros of purchasing value. A study developed by Instituto Cerdá [103] shows that company supply chain innovation rate in total innovation, not merely on innovation in sustainability, scores three times higher than the industry average.

(ii) Limited focus on short-term financial results (avoiding "short-termism"). The company does not focus on short-term financial results but rather on the gradual development of a model aimed at the long-term sustainability (" ... the long-term profit for the 5 key stakeholders is the investment ... "). In this particular case, implementing this SOI practice is facilitated by the ownership strategy of the firm: since its foundation, it belongs to a single family. Since it is not a public company (it does not trade in the stock exchange), it is easier to stick to long-term strategies, being isolated from the pressure of the financial markets.

(iii) Dynamic model-based strategy crafting. Even though it defies simple definitions, this practice permeates the strategic thinking at this company, particularly with respect to sustainable innovations. Basing their strategic process on a dynamic model of the company, centered around the interaction of the five key stakeholders mentioned above (C, E, S, SO, O) is a key tenant of their corporate culture [98-100]. An illustrative application of this model-based systemic thinking is their wholehearted adoption of the so-called "contrastation theory". This theory revolves around the notion of shifting the performance evaluation from results (basically, financial results) to the effort devoted to process and methods excellence and fulfillment. It is closely related to the above-mentioned emphasis on avoidance of financial short-termism, and thus it might be hard to replicate by companies with a different capital structure. Reminiscent of Forrester's (MIT) System Dynamics theory, it holds that results will eventually follow properly applied and guided effort. Furthermore, given the inherent delays (time lag between applying the effort and achieving the desired results; this is a period during which results are actually likely to move in the opposite direction, "performance dip"), focusing on results might actually lead to the wrong strategic feedback. This is particularly relevant in processes, such as innovation or sustainability management, that tend to produce positive results only after a protracted lag, and thus even more so in sustainable innovation. Based on this conceptual framework, and through an iterative process of application and continuous improvement, this company has perfected a tailored process to scientifically define each person's role in the company's processes and methods. This facilitates a more accurate evaluation of the effort devoted, and to trace the eventual contribution to the five guiding stakeholders.

There are two basic reasons for these quite significant SOI practices to not fit in the baseline model. The most obvious is that all three could be considered as transversal practices, rather than being basically circumscribed to just one dimension. Beyond that, their relationship with the other, dimension-specific practices was characterized by an enabling or supporting role. The impact of these practices to the overall SSCM was not additive, in the sense of their individual contribution being "summated" to the contribution of the dimension-specific practices. Rather, they contributed to the integrated SSCM basically by enabling and/or potentiating the effect of the other practices. Even though some synergic interaction also exists within dimension-specific practices, for these transversal SOI practices, this was not just a side effect but rather their defining nature.

As for the third objective (and the third Research Question), regarding adhocracy/ contingency, as well as the fourth objective, creating a tentative benchmark and exploring the model's usefulness as a self-appraisal tool, it is also worth highlighting that all SOI practices, even the dimension-specific ones, are to some degree contingent on the adopting company's traits. Therefore, even though such a contrasted, well-populated, and orderly structured model instance could indeed be a useful tentative benchmark, care should be exerted, like in any benchmarking exercise, to avoid attempting a simplistic replication of the benchmark model; due consideration should be given to the "fit" with the specific adopting company's traits, thus requiring an adaptation process. Nevertheless, here again 
the transversal SOI practices stand out as being particularly specific, contingent on the adopting company's core, defining characteristics (such as the ownership structure) and its strategy (such as the dynamic model-based strategy crafting discussed above). This result suggests that transversal SOI practices may be the major conduit through which the adopting company's strategy is reflected in its SSCM.

\section{Conclusions}

The application of the proposed baseline, descriptive sustainable innovation model in the chosen leading supply chain allowed the validation of the proposed descriptive/classificatory baseline model and confirmed its utility for the structuring and comprehensive reviewing of a company's SOI practices. However, this analysis also revealed three significant, and conceptually distinctive, SOI practices that did not fit in the baseline model. These key overlooked ingredients revealed the need to adapt the baseline model, thus being directly related to the objective of " ... Increasing the structural coherence and explicative capacity of the model by complementing it with previously overlooked key components, and by prodding into the interrelationships ... ". These three practices are: (i) integral supply chain approach, all the way up to the primary sector; this involves a level of coordination in the chain enabling innovative practices to circulate throughout the supply chain to the furthermost upstream suppliers, (ii) avoiding short-termism. This factor might be more idiosyncratic (highly related to the ownership structure) and thus harder to extrapolate to other companies, and is related to the need to adopt a longer-term vision of the economic objectives, as opposed to the currently prevalent short-termism. The study's authors consider that an excessive short-termism can put at risk supply chain models that rely on innovation mechanisms to achieve comprehensive sustainability. (iii) Dynamic model-based strategy crafting. This SOI practice, closely linked with the company's strategy, is also somehow enabled by the previous two, and might be the most conceptually relevant finding in this research project. It combines integrated planning/management with the avoidance of the short-term dynamics that might otherwise derail, through the negative feedback loops that appear in processes such as innovation and sustainability management that involve substantial time delays, to enable shifting the focus from the results to its causes (processes and methods). Shifting the top management focus "upstream" in the causal chain, while systematically managing the feedback loops through an integrated strategy grounded in System Dynamics, is a powerful notion, which might have applications beyond SSC innovation.

Furthermore, analogously to the value chain's "Support Activities", these three SOI practices are transversal, spanning all three dimensions (Economic, Environmental, Social), and, rather than directly improving sustainability, they indirectly promote it by enhancing the effectivity of the "Primary SOI practices" (like the "Primary Activities" that directly add value in the value chain model). Thus, concerning the objective of "validate, or further develop if needed, the proposed classificatory framework", the authors propose to include in the model, alongside the initial "primary SOI practices", a second category of transversal "support SOI practices", exemplified by the three found here.

Another defining trait of these of transversal "support SOI practices" is an even higher level of contingency on the key characteristics of the adopting company and on its strategy, thus suggesting they may play a major role in the strategic tailoring of the SSCM.

Regarding the objective of "creating a tentative benchmark against which less-developed SSCIM implementations could measure themselves", the authors believe that Table 3, complemented with the additional "Support SOI practices" being proposed, could serve, at a minimum, as a starting point, enabling companies evaluating themselves with this model to compare their current situation with that of an established leader. As for "exploring the model's usefulness to develop innovation-based improvement plans as a self-appraisal tool", the experience in applying the enhanced model to this case suggests that it could provide a practicable framework within which to structure SSCIM improvement plans as well as their monitoring. A key contribution here, however, would be the inclusion in the model 
(also for benchmarking/self-appraisal purposes) of the "support SOI practices". Regarding "exploring the contingency relationship between the resulting model and the core traits ...", as discussed in the previous section, all SOI practices, even the dimension-specific ones, are to some degree contingent on the adopting company's traits, thus requiring careful adaptation while extrapolating them to other companies/SCs. Additionally, a core contribution of this study would be the qualitatively higher contingent nature of the "support SOI practices" on the adopting company's traits and strategy, to the extent that they could be considered the major conduit through which its strategy is reflected in its SSCM.

Thus, theoretical contributions from this study that add to the existing body of knowledge could be summarized as: (i) validation of the proposed descriptive/classificatory baseline model and of its usefulness for SOI practices structuring and reviewing purposes, (ii) further development of the model upon identification of key overlooked ingredients, by incorporating a second category of transversal "support SOI practices", exemplified by the three described above and, (iii) recognition of the highly adhocratic nature of these transversal practices, thus hinting that they may be a major conduit for reflecting the adopting company's strategy in its SSCM.

As for the resulting insights for practice and policy, some of them derive directly from these theoretical contributions in the form of an extended SOI practices model that not only includes additional categories but also delves into their interrelationships and on their contingency on the adopting company's characteristics and strategy. At a more immediate level, as described above, Table 3, complemented with the additional support OI practices, could be used as a starting point in benchmarking exercises, as well as a springboard within which to structure SSCIM improvement plans.

Regarding limitations and threats to validity of the study, and consequently future, follow-up research, they mostly inherently stem from the nature of an in-depth case study. As such, and in spite of its potential usefulness, it is intrinsically exploratory research, whose tentative conclusions should be validated through practical application and by further studies in additional cases/organizational settings. Therefore, the authors intend to apply this extended model to a larger sample of companies belonging to the same sector or different sectors in order to establish the model applicability and potential roadblocks for its deployment that could suggest changes and proper adaptations. The authors also aim to carry out a study to identify barriers, such as those identified by Gupta et al. [68], which could hinder the extensive application of the model.

Author Contributions: Conceptualization, J.M.-B., L.I.-S., I.G.-G. and A.D.-H.; methodology, J.M.-B., L.I.-S., I.G.-G. and A.D.-H.; validation: J.M.-B. and A.D.-H.; formal analysis, J.M.-B., L.I.-S., I.G.-G. and A.D.-H.; investigation, J.M.-B., L.I.-S., I.G.-G. and A.D.-H.; writing-original draft preparation, J.M.-B., L.I.-S., I.G.-G. and A.D.-H.; writing-review and editing, J.M.-B., L.I.-S., I.G.-G. and A.D.-H.; supervision, J.M.-B., L.I.-S., I.G.-G. and A.D.-H. All authors have read and agreed to the published version of the manuscript.

Funding: This work has been supported by the Madrid Government (Comunidad de Madrid-Spain) under the Multiannual Agreement with UC3M in the line of Excellence of University Professors (EPUC3M20), and in the context of the V PRICIT (Regional Program of Research and Technological Innovation).

Institutional Review Board Statement: Not applicable.

Informed Consent Statement: Not applicable.

Data Availability Statement: Data sharing not applicable.

Conflicts of Interest: The authors declare no conflict of interest.

\section{References}

1. Brundtland Commission. Brundtland Report: Our Common Future; WCED (World Commission on the Environment and Development): New York, NY, USA, 1987.

2. Shrivastava, P. The role of corporations in achieving ecological sustainability. Acad. Manag. Rev. 1995, 20, 936-960. [CrossRef] 
3. Rexhague, J.; Murphy, D. Sustainable Development: From Bruntland to Rio 2012 (Background Paper); UN: New York, NY, USA, 2010; pp. 15-27.

4. Bottani, E.; Tebaldi, L.; Lazzari, I.; Casella, G. A model for assessing economic and environmental sustainability dimensions of a fashion supply chain and a case study. IFAC-Pap. OnLine 2019, 52, 361-366. [CrossRef]

5. Cooper, M.C.; Lambert, D.M.; Pagh, J.D. Supply chain management: More than a new name for logistics. Int. J. Logist. Manag. 1997, 8, 1-14. [CrossRef]

6. Chopra, S.; Meindl, P. Supply Chain Management. Strategy, Planning \& Operation. In Das Summa Summarum Des Management; Gabler: Wiesbaden, Germany, 2017; pp. 265-275.

7. Mentzer, J.T.; DeWitt, W.; Keebler, J.S.; Min, S.; Nix, N.W.; Smith, C.D.; Zacharia, Z.G. Defining supply chain management. J. Bus. Logist. 2001, 22, 1-25. [CrossRef]

8. Lambert, D.M. Supply Chain Management: Processes, Partnerships, Performance; Supply Chain Management Institute: Sarasota, FL, USA, 2008; pp. 16-25.

9. Van Bommel, H.W. A conceptual framework for analyzing sustainability strategies in industrial supply networks from an innovation perspective. J. Clean. Prod. 2011, 19, 895-904. [CrossRef]

10. Ashby, A.; Leat, M.; Hudson-Smith, M. Making connections: A review of supply chain management and sustainability literature. Supply Chain Manag. Int. J. 2012, 17, 497-516. [CrossRef]

11. Rajeev, A.; Pati, R.K.; Padhi, S.S.; Govindan, K. Evolution of sustainability in supply chain management: A literature review. J. Clean. Prod. 2017, 162, 299-314. [CrossRef]

12. Seuring, S.; Müller, M. From a literature review to a conceptual framework for sustainable supply chain management. J. Clean. Prod. 2018, 16, 1699-1710. [CrossRef]

13. Ageron, B.; Gunasekaran, A.; Spalanzani, A. Sustainable supply management: An empirical study. Int. J. Prod. Econ. 2012, 140, 168-182. [CrossRef]

14. Ahi, P.; Searcy, C. A comparative literature analysis of definitions for green and sustainable supply chain management. J. Clean. Prod. 2013, 52, 329-341. [CrossRef]

15. Srivastava, S.K. Green Supply-chain Management: A State-Of-the-Art Literature review. Int. J. Manag. Rev. 2007, 9, 53-80. [CrossRef]

16. Diabat, A.; Govindan, K. An analysis of the drivers affecting the implementation of green supply chain management. Resour. Conserv. Recycl. 2011, 55, 659-667. [CrossRef]

17. Green, K.W., Jr.; Zelbst, P.J.; Meacham, J.; Bhadauria, V.S. Emerald Article: Green supply chain management practices: Impact on performance. Supply Chain Manag. 2012, 17, 202-216. [CrossRef]

18. Roehrich, J.K.; Hoejmose, S.U.; Overland, V. Driving green supply chain management performance through supplier selection and value internalisation. Int. J. Oper. Prod. Manag. 2017, 37, 489-509. [CrossRef]

19. Brammer, S.; Walker, H. Sustainable procurement in the public sector: An international comparative study. Int. J. Oper. Prod. Manag. 2011, 31, 452-476. [CrossRef]

20. Roehrich, J.K.; Grosvold, J.; Hoejmose, S.U. Reputational risks and sustainable supply chain management: Decision making under bounded rationality. Int. J. Oper. Prod. Manag. 2014, 34, 695-719. [CrossRef]

21. Sarkis, J.; Meade, L.M.; Presley, A.R. Incorporating sustainability into contractor evaluation and team formation in the built environment. J. Clean. Prod. 2012, 31, 40-53. [CrossRef]

22. Crum, M.; Poist, R.; Carter, C.R.; Easton, P.L. Sustainable supply chain management: Evolution and future directions. Int. J. Phys. Distrib. Logist. Manag. 2011, 41, 46-52.

23. Carter, C.R.; Rogers, D.S. A framework of sustainable supply chain management: Moving toward new theory. Int. J. Phys. Distrib. Logist. Manag. 2008, 38, 360-387. [CrossRef]

24. Koberg, E.; Longoni, A. A systematic review of sustainable supply chain management in global supply chains. J. Clean. Prod. 2019, 207, 1084-1098. [CrossRef]

25. Elkington, J. Cannibals with Forks: The Triple Bottom Line of 21st Century; Capstone: Oxford, UK, 1997.

26. Rego, A.; Cunha, M.P.; Polónia, D. Corporate sustainability: A view from the top. J. Bus. Ethics 2017, 143, 133-157. [CrossRef]

27. Joyce, A.; Paquin, R.L. The triple layered business model canvas: A tool to design more sustainable business models. J. Clean. Prod. 2016, 135, 1474-1486. [CrossRef]

28. Dey, P.K.; Malesios, C.; De, D.; Chowdhury, S.; Abdelaziz, F.B. Could lean practices and process innovation enhance supply chain sustainability of small and medium-sized enterprises? Bus. Strategy Environ. 2019, 28, 582-598. [CrossRef]

29. Hassini, E.; Surti, C.; Searcy, C. A literature review and a case study of sustainable supply chains with a focus on metrics. Int. J. Prod. Econ. 2012, 140, 69-82. [CrossRef]

30. Tebaldi, L.; Bigliardi, B.; Bottani, E. Sustainable supply chain and innovation: A review of the recent literature. Sustainability 2018, 10, 3946. [CrossRef]

31. Dubey, R.; Gunasekaran, A.; Papadopoulos, T.; Childe, S.J.; Shibin, K.T.; Wamba, S.F. Sustainable supply chain management: Framework and further research directions. J. Clean. Prod. 2017, 142, 1119-1130. [CrossRef]

32. Grosvold, J.; Hoejmose, S.U.; Roehrich, J.K. Squaring the circle: Management, measurement and performance of sustainability in supply chains. Supply Chain Manag. Int. J. 2014, 19, 292-305. [CrossRef] 
33. Hervani, A.A.; Helms, M.M.; Sarkis, J. Performance measurement for green supply chain management. Benchmarking Int. J. 2005, 12, 330-353. [CrossRef]

34. Preuss, L. Addressing sustainable development through public procurement: The case of local government. Supply Chain Manag. Int. J. 2009, 14, 213-223. [CrossRef]

35. Schaltegger, S.; Lüdeke-Freund, F.; Hansen, E.G. Business cases for sustainability: The role of business model innovation for corporate sustainability. Int. J. Innov. Sustain. Dev. 2012, 6, 95-119. [CrossRef]

36. Van Tulder, R.; Van Wijk, J.; Kolk, A. From chain liability to chain responsibility. J. Bus. Ethics 2009, 85, 399-412. [CrossRef]

37. Walker, H.; Jones, N. Sustainable supply chain management across the UK private sector. Supply Chain Manag. Int. J. 2012, 17, 15-28. [CrossRef]

38. Montiel, I. Corporate social responsibility and corporate sustainability: Separate pasts, common futures. Organ. Environ. 2008, 21, 245-269. [CrossRef]

39. Sancha, C.; Gimenez, C.; Sierra, V. Achieving a socially responsible supply chain through assessment and collaboration. J. Clean. Prod. 2016, 112, 1934-1947. [CrossRef]

40. Isasi-Sanchez, L.; Morcillo-Bellido, J.; Ortiz-Gonzalez, J.; Duran-Heras, A. Synergic Sustainability Implications of Additive Manufacturing in Automotive Spare Parts: A Case Analysis. Sustainability 2020, 12, 8461. [CrossRef]

41. Vermeulen, W.J.; Seuring, S. Sustainability through the market-the impacts of sustainable supply chain management: Introduction. Sustain. Dev. 2009, 17, 269-273. [CrossRef]

42. Carter, C.R.; Hatton, M.R.; Wu, C.; Chen, X. Sustainable supply chain management: Continuing evolution and future directions. Int. J. Phys. Distrib. Logist. Manag. 2019, 50, 122-146. [CrossRef]

43. Gimenez, C.; Tachizawa, E.M. Extending sustainability to suppliers: A systematic literature review. Supply Chain Manag. Int. J. 2012, 17, 531-543. [CrossRef]

44. Ciccullo, F.; Pero, M.; Gosling, J.; Caridi, M.; Purvis, L. When Sustainability Becomes an Order Winner: Linking Supply Uncertainty and Sustainable Supply Chain Strategies. Sustainability 2020, 12, 6009. [CrossRef]

45. Zimon, D.; Tyan, J.; Sroufe, R. Implementing Sustainable Supply Chain Management: Reactive, Cooperative, and Dynamic Models. Sustainability 2019, 11, 7227. [CrossRef]

46. Beske-Janssen, P.; Johnson, M.P.; Schaltegger, S. 20 years of performance measurement in sustainable supply chain managementwhat has been achieved? Supply Chain Manag. Int. J. 2015, 20, 664. [CrossRef]

47. Hoejmose, S.U.; Brammer, S.; Millington, A. Green supply chain management: The role of trust and top management in B2B and B2C markets. Ind. Mark. Manag. 2012, 41, 609-620. [CrossRef]

48. Govindan, K.; Rajendran, S.; Sarkis, J.; Murugesan, P. Multi criteria decision making approaches for green supplier evaluation and selection: A literature review. J. Clean. Prod. 2015, 98, 66-83. [CrossRef]

49. Wu, D.D.; Zhang, Y.; Wu, D.; Olson, D.L. Fuzzy multi-objective programming for supplier selection and risk modeling: A possibility approach. Eur. J. Oper. Res. 2010, 200, 774-787. [CrossRef]

50. Gold, S.; Seuring, S.; Beske, P. Sustainable supply chain management and inter-organizational resources: A literature review. Corp. Soc. Responsib. Environ. Manag. 2010, 17, 230-245. [CrossRef]

51. Wiedmann, T.; Minx, J. A definition of 'carbon footprint'. Ecol. Econ. Res. Trends 2008, 1, 1-11.

52. Damanpour, F. Organizational innovation: A meta-analysis of effects of determinants and moderators. Acad.Manag. J. 1991, 34, 555-590.

53. Lambert, D.M.; Cooper, M.C.; Pagh, J.D. Supply chain management: Implementation issues and research opportunities. Int. J. Logist. Manag. 1998, 9, 1-20. [CrossRef]

54. Sezen, B.; Cankaya, S.Y. Effects of green manufacturing and eco-innovation on sustainability performance. Procedia-Soc. Behav. Sci. 2013, 99, 154-163. [CrossRef]

55. Mangun, D.; Thurston, D. Incorporating component reuse, remanufacture, and recycle into product portfolio design. IEEE Trans. Eng. Manag. 2002, 49, 479-490. [CrossRef]

56. Pagell, M.; $\mathrm{Wu}, \mathrm{Z}$. Building a more complete theory of sustainable supply chain management using case studies of 10 exemplars. J. Supply Chain Manag. 2009, 45, 37-56. [CrossRef]

57. Malone, T.W.; Crowston, K. The interdisciplinary study of coordination. ACM Comput. Surv. (CSUR) 1994, 26, 87-119. [CrossRef]

58. Horbach, J. (Ed.) Indicator Systems for Sustainable Innovation; Physica-Verlag: Heidelberg, Germany, 2005.

59. Boons, F.; Lüdeke-Freund, F. Business models for sustainable innovation: State-of-the-art and steps towards a research agenda. J. Clean. Prod. 2013, 45, 9-19. [CrossRef]

60. Beise, M.; Rennings, K. Lead markets and regulation: A framework for analyzing the international diffusion of environmental innovations. Ecol. Econ. 2005, 52, 5-17. [CrossRef]

61. Kusi-Sarpong, S.; Gupta, H.; Sarkis, J. A supply chain sustainability innovation framework and evaluation methodology. Int. J. Prod. Res. 2019, 57, 1990-2008. [CrossRef]

62. Lozano, R. A holistic perspective on corporate sustainability drivers. Corp. Soc. Responsib. Environ. Manag. 2015, $22,32-44$. [CrossRef]

63. Gao, D.; Xu, Z.; Ruan, Y.Z.; Lu, H. From a systematic literature review to integrated definition for sustainable supply chain innovation (SSCI). J. Clean. Prod. 2017, 142, 1518-1538. [CrossRef] 
64. Costantini, V.; Crespi, F.; Marin, G.; Paglialunga, E. Eco-innovation, sustainable supply chains and environmental performance in European industries. J. Clean. Prod. 2017, 155, 141-154. [CrossRef]

65. De Vargas Mores, G.; Finocchio, C.P.S.; Barichello, R.; Pedrozo, E.A. Sustainability and innovation in the Brazilian supply chain of green plastic. J. Clean. Prod. 2018, 177, 12-18. [CrossRef]

66. Silva, G.M.; Gomes, P.J.; Sarkis, J. The role of innovation in the implementation of green supply chain management practices. Bus. Strategy Environ. 2019, 28, 819-832. [CrossRef]

67. Gupta, H.; Barua, M.K. A framework to overcome barriers to green innovation in SMEs using BWM and Fuzzy TOPSIS. Sci. Total Environ. 2018, 633, 122-139. [CrossRef] [PubMed]

68. Gupta, H.; Kusi-Sarpong, S.; Rezaei, J. Barriers and overcoming strategies to supply chain sustainability innovation. Resour. Conserv. Recycl. 2020, 161, 104819. [CrossRef]

69. Gouda, S.K.; Saranga, H. Sustainable supply chains for supply chain sustainability: Impact of sustainability efforts on supply chain risk. Int. J. Prod. Res. 2018, 56, 5820-5835. [CrossRef]

70. Sanchis, R.; Duran-Heras, A.; Poler, R. Optimising the Preparedness Capacity of Enterprise Resilience Using Mathematical Programming. Mathematics 2020, 8, 1596. [CrossRef]

71. Doherty, B.; Haugh, H.; Lyon, F. Social enterprises as hybrid organizations: A review and research agenda. Int. J. Manag. Rev. 2014, 16, 417-436. [CrossRef]

72. Adams, R.; Jeanrenaud, S.; Bessant, J.; Denyer, D.; Overy, P. Sustainability-oriented innovation: A systematic review. Int. J. Manag. Rev. 2016, 18, 180-205. [CrossRef]

73. Carroll, A.B.; Shabana, K.M. The business case for corporate social responsibility: A review of concepts, research and practice. Int. J. Manag. Rev. 2010, 12, 85-105. [CrossRef]

74. Owen, R.; Stilgoe, J.; Macnaghten, P.; Gorman, M.; Fisher, E.; Guston, D. A framework for responsible innovation. In Responsible Innovation: Managing the Responsible Emergence of Science and Innovation in Society; Wiley: New York, NY, USA, 2013 ; pp. 27-50.

75. Seebode, D.; Jeanrenaud, S.; Bessant, J. Managing innovation for sustainability. RED Manag. 2012, 42, $195-206$.

76. Klewitz, J.; Hansen, E.G. Sustainability-oriented innovation of SMEs: A systematic review. J. Clean. Prod. 2014, 65, 57-75. [CrossRef]

77. Fabbe-Costes, N.; Jahre, M. Supply chain integration and performance: A review of the evidence. Int. J. Logist. Manag. 2008, 19, 130-154. [CrossRef]

78. Genovese, A.; Acquaye, A.A.; Figueroa, A.; Koh, S.L. Sustainable supply chain management and the transition towards a circular economy: Evidence and some applications. Omega 2017, 66, 344-357. [CrossRef]

79. Yang, Y.; Wang, Y. Supplier Selection for the Adoption of Green Innovation in Sustainable Supply Chain Management Practices: A Case of the Chinese Textile Manufacturing Industry. Processes 2020, 8, 717. [CrossRef]

80. Wang, Y.; Yang, Y. Analyzing the green innovation practices based on sustainability performance indicators: A Chinese manufacturing industry case. Environ. Sci. Pollut. Res. 2021, 28, 1181-1203. [CrossRef]

81. Baumgartner, R.J.; Rauter, R. Strategic perspectives of corporate sustainability management to develop a sustainable organization. J. Clean. Prod. 2017, 140, 81-92. [CrossRef]

82. Eisenhardt, K.M. Building theories from case research. Acad. Manag. Rev. 1989, 14, 532-550. [CrossRef]

83. Voss, C. Case Research in Operations Management. In Researching Operations Management; Routledge: London, UK, 2010; pp. 176-209.

84. Yin, R.K. Case Study Research: Design and Methods; Sage Publications: Beverly Hill, CA, USA, 1994.

85. Holmström, J.; Ketokivi, M.; Hameri, A.P. Bridging practice and theory: A design science approach. Decis. Sci. 2009, 40, 65-87. [CrossRef]

86. Ketokivi, M.; Choi, T. Renaissance of case research as a scientific method. J. Oper. Manag. 2014, 32, 232-240. [CrossRef]

87. Gdf. Estudio del Retail en Europa 2019. Available online: https://www.gfk.com/fileadmin/user_upload/country_one_pager/ ES/documents/2019-06-27_NdP_GfK_El_Retail_Europeo_en_2019_VD.pdf (accessed on 15 September 2020).

88. Jørgensen, S.; Pedersen, L.J.T. Toward smart and sustainable business models in retail. In Innovation for Sustainability; Palgrave Macmillan: London, UK, 2019; pp. 177-192.

89. Risso, M.; Tavino, S. Sustainable Initiatives and Organizational Reshaping in Food Retailers. In Handbook of Research on Retailing Techniques for Optimal Consumer Engagement and Experiences; IGI Global: Hershey, PA, USA, 2020; pp. 462-479.

90. Durieu, X. How Europe's retail sector helps promote sustainable production and consumption. Ind. Environ. 2003, 26, 7-9.

91. Ruiz-Real, J.L.; Uribe-Toril, J.; Gázquez-Abad, J.C.; de Pablo Valenciano, J. Sustainability and retail: Analysis of global research. Sustainability 2019, 11, 14. [CrossRef]

92. Morcillo-Bellido, J.; Duran-Heras, A. Sustainability Governance Mechanisms in Supply Chains: An Application in the Retail Sector. Sustainability 2020, 12, 6911. [CrossRef]

93. Deloitte. Global Powers of Retailing 2018-Transformative Change, Reinvigorated Commerce; Deloitte: London, UK, 2018.

94. Eurostat. Statistical Office of the European Union-Database. Available online: https://ec.europa.eu/eurostat/data/database (accessed on 15 March 2020).

95. Ferreira, A.; Duarte Pinheiro, M.; de Brito, J.; Mateus, R. Combined carbon and energy intensity benchmarks for sustainable retail stores. Energy 2018, 165, 877-889. [CrossRef] 
96. Mayorova, E. Corporate social responsibility disclosure: Evidence from the European retail sector. Entrep. Sustain. Issues 2019, 7, 891-905. [CrossRef]

97. Naidoo, M.; Gasparatos, A. Corporate Environmental Sustainability in the retail sector: Drivers, strategies and performance measurement. J. Clean. Prod. 2018, 203, 125-142. [CrossRef]

98. Mercadona. Memoria Anual 2017. Available online: https://info.mercadona.es/document/es/mercadona-memoria-anual-2017 .pdf (accessed on 10 January 2020).

99. Mercadona. Memoria Anual 2018. Available online: https://info.mercadona.es/document/es/mercadona-memoria-anual-2018 .pdf (accessed on 15 March 2020).

100. Mercadona. Memoria Anual 2019. Available online: https://info.mercadona.es/document/es/mercadona-memoria-anual-2019 .pdf (accessed on 20 September 2020).

101. Mercadona. Memoria Medioambiental 2017-2018. Available online: https://info.mercadona.es/document/es/memoriamedioambiental-2017-2018.pdf (accessed on 10 January 2021).

102. Dahlmann, F.; Roehrich, J. Sustainable supply chain management and partner engagement to manage climate change information. Bus. Strategy Environ. 2019, 28, 1632-1647. [CrossRef]

103. Instituto Cerdá. Observatorio de la Innovación en España; Instituto Cerdá: Barcelona, Spain, 2020. Available online: http:/ / www. asedas.org/wp-content/uploads/2020/03/Observatorio-Innovacion-GC-2020-Institut-Cerda.pdf (accessed on 15 October 2020). 